\title{
Active tectonics along the submarine slope of south-eastern Sicily and the source of the 11 January 1693 earthquake and tsunami
}

\author{
A. Argnani ${ }^{1}$, A. Armigliato ${ }^{2}$, G. Pagnoni ${ }^{2}$, F. Zaniboni ${ }^{2}$, S. Tinti ${ }^{2}$, and C. Bonazzi ${ }^{1}$ \\ ${ }^{1}$ ISMAR-CNR, Istituto di Scienze Marine, Sede di Bologna, Via Gobetti 101, 40129 Bologna, Italy \\ ${ }^{2}$ University of Bologna, Department of Physics, Sector of Geophysics, Viale Carlo Berti Pichat 8, 40127 Bologna, Italy \\ Correspondence to: A. Argnani (andrea.argnani@ismar.cnr.it)
}

Received: 26 July 2011 - Revised: 23 February 2012 - Accepted: 7 March 2012 - Published: 7 May 2012

\begin{abstract}
South-eastern Sicily has been affected by large historical earthquakes, including the 11 January 1693 earthquake, considered the largest magnitude earthquake in the history of Italy $\left(M_{\mathrm{w}}=7.4\right)$. This earthquake was accompanied by a large tsunami (tsunami magnitude 2.3 in the MurtyLoomis scale adopted in the Italian tsunami catalogue by Tinti et al., 2004), suggesting a source in the near offshore. The fault system of the eastern Sicily slope is characterised by NNW-SSE-trending east-dipping extensional faults active in the Quaternary. The geometry of a fault that appears currently active has been derived from the interpretation of seismic data, and has been used for modelling the tsunamigenic source. Synthetic tide-gauge records from modelling this fault source indicate that the first tsunami wave polarity is negative (sea retreat) in almost all the coastal nodes of eastern Sicily, in agreement with historical observations. The outcomes of the numerical simulations also indicate that the coastal stretch running from Catania to Siracusa suffered the strongest tsunami impact, and that the highest tsunami waves occurred in Augusta, aslo in agreement with the historical accounts. A large-size submarine slide (almost $5 \mathrm{~km}^{3}$ ) has also been identified along the slope, affecting the footwall of the active fault. Modelling indicates that this slide gives non-negligible tsunami signals along the coast; though not enough to match the historical observations for the 1693 tsunami event. The earthquake alone or a combination of earthquake faulting and slide can possibly account for the large run up waves reported for the 11 January 1693 event.
\end{abstract}

\section{Introduction}

The steep slope that bounds eastern Sicily and connect the shelf to the deep Ionian basin, has long been recognised to be part of a major tectonic feature of the central Mediterranean, the Malta Escarpment (Fig. 1; Scandone et al., 1981); its age, as well as the age of the adjacent Ionian Basin, remains controversial, ranging from Late Triassic to Early Cretaceous (e.g. Argnani and Bonazzi, 2005 and references therein).

The south-eastern region of Sicily is currently the site of significant seismic activity that has been recorded in recent instrumental catalogues (Chiarabba et al., 2005; Musumeci et al., 2005) and historical chronicles (Boschi et al., 1995a and b). In particular, it has been affected by large historical earthquakes, one of which, the 11 January 1693 earthquake, has been considered as the largest earthquake in the history of Italy $\left(M_{\mathrm{w}}=7.4\right.$; CPTI Working Group, 2004). This earthquake was accompanied by a large tsunami (estimated tsunami magnitude 2.3, Tinti et al., 2004), suggesting a source located in the near offshore. However, the identification of the tectonic structure responsible for the 1693 earthquake is still a matter of debate. Some authors proposed as source of the 1693 earthquake an active fault system identified and mapped in detail off south-east Sicily (Argnani and Bonazzi, 2005). On the basis of macroseismic intensity field, some authors assumed an earthquake source located onshore (e.g. DISS Working Group, 2010). The suggested onshore faults, however, are still poorly documented, and have negligible tsunamigenic potential. For example, the two faults indicated by the DISS Working Group (2010), as possibly responsible for the 11 January 1693 earthquake (ITIS106 and ITIS074), are almost completely located inland, have magnitudes (6.0 and 6.6, respectively) significantly smaller than 


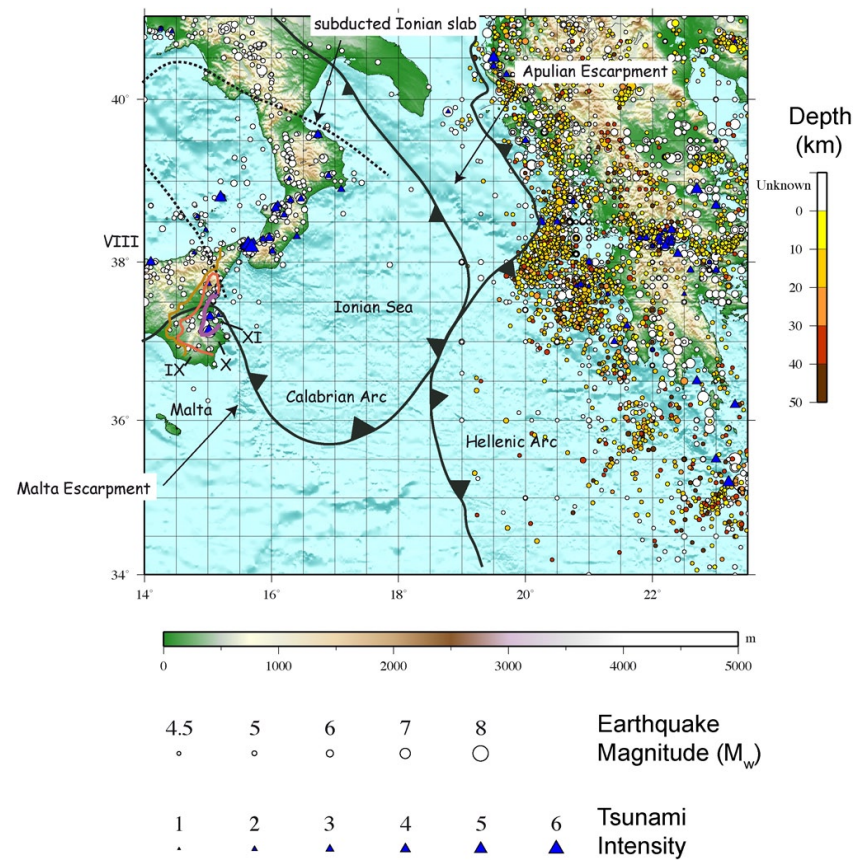

Fig. 1. Seismicity and main geodynamic features of the Ionian region with the main geological features along the coast of Sicily and Calabria. The historical earthquakes have been compiled by suitably combining and homogenizing different national catalogues (see in particular CPTI Working Group, 2004; Papaioannou et al., 2000; Papazachos et al., 2007). Historical tsunamis are from Tinti et al. (2001b, 2004). The contour lines of maximum felt macroseismic intensity (over IX) for south-eastern Sicily are also shown (after Boschi et al., 1995a).

what reported in the CPTI catalogue and are then unable to produce any significant seafloor permanent deformation required for tsunami generation.

Making use of numerical modelling of tsunamigenic sources, this paper aims at confirming that (i) the active faults located off south-east Sicily, whose geometry was obtained as the result of seismic profiles interpretation, can account for the 1693 tsunami, as reported in historical chronicles, and (ii) a large submarine landslide, which might be related to the same fault activity, can be considered a possible additional factor for the generation of the tsunami.

\section{Geological setting of the eastern Sicily slope}

The region encompassing south-western Calabria and eastern Sicily is known for being tectonically active (e.g. Argnani et al., 2009a and references therein). The disastrous historical earthquakes that struck eastern Sicily several times, and in particular Catania and Messina, as well as southern Calabria, were quite likely originated by marine tectonic structures (Argnani and Bonazzi, 2005). Moreover, the largest tsunamis that affected the Italian coasts originated from this marine region. Two examples are the 28 December 1908 tsunami, which hit north-eastern Sicily and southern Calabria with wave heights up to $13 \mathrm{~m}$, and the 11 January 1693 tsunami that affected the whole coast of eastern Sicily and was felt as far as Malta, to the south, and the Aeolian Island, to the north (Tinti et al., 2004). The January 1693 event is a case of particular interest as the location of the source fault is still highly debated. Different onshore faults were proposed by various authors (D'Addezio and Valensise, 1991; Sirovich and Pettenati, 1999, 2001; DISS Working Group, 2010), most of which, however, have limited geological evidence. Further, the intensity map for this earthquake shows that the highest intensity values (X-XI and XI according to the EMS 98 scale) were found for towns located on the coast or very close to the coast (see Barbano and Rigano, 2001), suggesting that the earthquake source was located offshore. Moreover, the large tsunami that was associated with this earthquake cannot be explained by the proposed onshore faults without invoking a different source for the tsunami: an earthquake-triggered submarine landslide. On the other hand, recent geophysical surveys have shown that active faults do exist off eastern Sicily (Bianca et al., 1999; Argnani and Bonazzi, 2005) and furthermore that slope failures occurred offshore (Argnani and Bonazzi, 2005). The relevant characteristics of these active tectonic structures are described below, together with the description of a large submarine slide that has been identified off Augusta (hereafter named Augusta slide).

\subsection{Faults}

The segment of the slope extending north of Siracusa is characterised by the presence of NNW-SSE-trending, eastdipping extensional faults located along the morphological escarpment and a few km east of it (Fig. 2). Active faulting is well documented by seismic profiles that show half grabens filled by sediments with growth geometry and fault surfaces, producing morphological scarps at the sea floor (Argnani and Bonazzi, 2005). In addition, multibeam bathymetry data acquired in the western Ionian sea (Marani et al., 2004) show linear features correlating with seafloor topography, further supporting the presence of active faults cutting the sea floor.

Profile MESC 08 shows a half-graben basin, filled with sediments up to $1 \mathrm{~s}$ (TWT) thick, and bounded to the west by two extensional faults, with the western one being an active splay of the master fault (Fig. 3). Wedging of reflections, identifying growth strata, can be observed within the graben; the age of the infilling sediments has been inferred to cover the whole Quaternary on the basis of seismo-stratigraphic relationship (Argnani and Bonazzi, 2005). On a depth migrated version of this profile the dip angle of the faults is about $30^{\circ}$. Although such dip is small for a typical normal fault, it is worth mentioning that the normal fault inferred to be responsible for the 1908 Messina earthquake has a similar small dip (e.g. Valensise and Pantosti, 1992; Pino et al. 2009). 


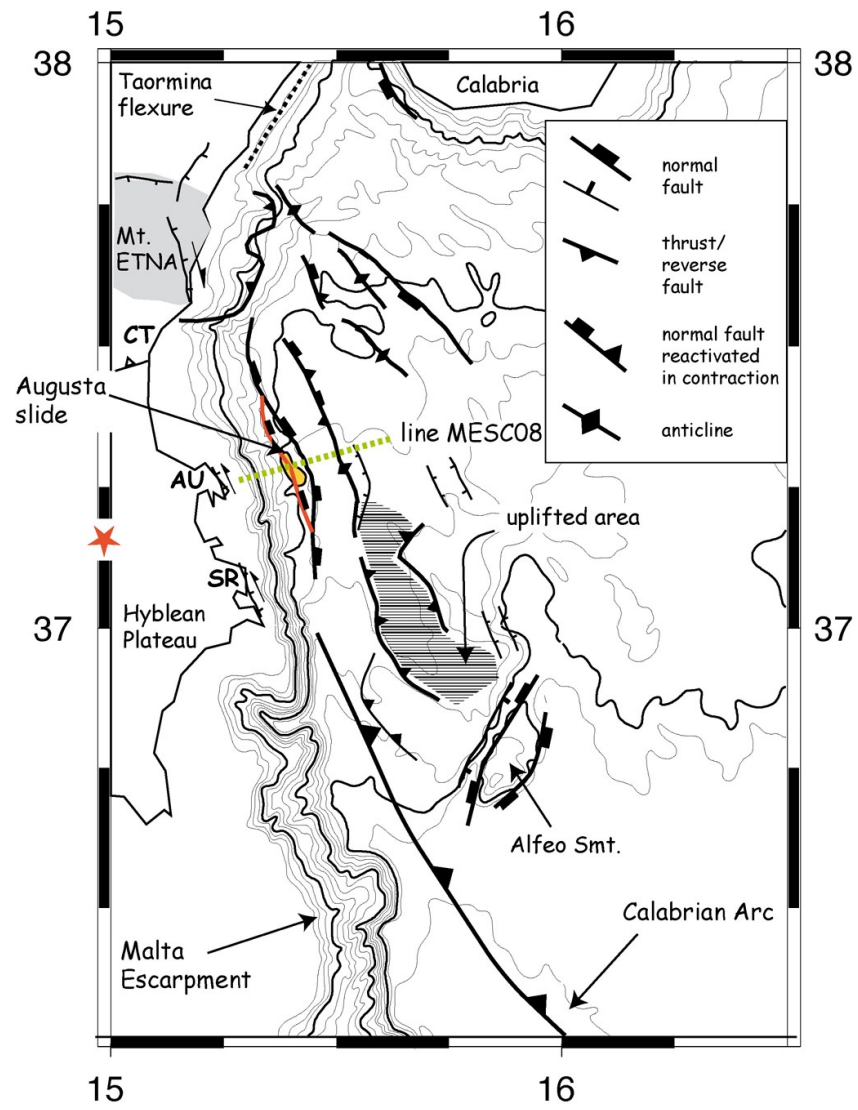

Fig. 2. Bathymetry of the eastern Sicily offshore with the simplified structural map based on the MESC seismic survey (Argnani and Bonazzi, 2005). Onshore data are only schematic and are mainly taken from Lanzafame and Bousquet (1997) and Adam et al. (2000). The active fault is marked in red. The trace of seismic profile MESC 08 is indicated as a thick dashed green line, whereas the orange field represents the extent of the Augusta slide. The red star indicates the approximated location of the onshore 11 January 1693 earthquake epicenter suggested by CPTI Working Group (2004). CT, AU, and SR indicate the location of the cities of Catania, Augusta and Siracusa, respectively.

The active tectonic features in the segment of the Malta Escarpment between Catania and the Alfeo Seamount present a remarkable complexity. Nevertheless, the extensional faults described above appear as the major feature. In particular, the normal fault splay that cuts the sea floor (Fig. 2) is long enough (about $30 \mathrm{~km}$ ) to generate large earthquakes and tsunamis, and can be taken as a likely source for a 1693type earthquake. The map trace and the attitude of the active normal fault splay have been used as input for the tsunami numerical modelling.

\subsection{Landslide}

A large-scale submarine landslide has been imaged on seismic profiles at the foot of the eastern Sicily slope, along the Malta escarpment, at a water depth around $2000 \mathrm{~m}$. This
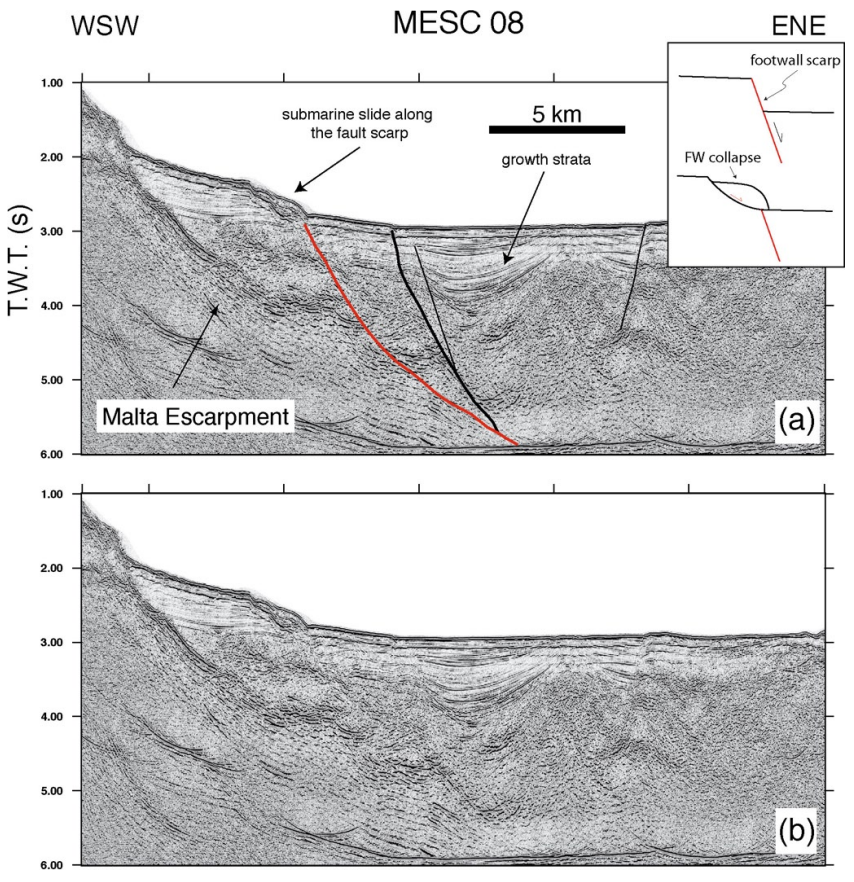

Fig. 3. Seismic profile MESC 08. (a) Interpreted line showing the structural features in the northern sector of the eastern Sicily slope. The steep eastward-dipping package of reflectors represents the Malta Escarpment. Note the two normal faults, one of which is active (in red) and cuts the sea floor. The slide is affecting the footwall of the active splay of the major normal fault, located to the west. Vertical exaggeration ca. 3.5. The inset shows the conceptual interpretation of the slide/fault relationship. (b) Non interpreted line. The detail of the slide is given in Fig. 4. Location in Fig. 2.

slide occurred at the base of the scarp of the active fault and affected the footwall sediments (Figs. 3 and 4). Seismic surveys allowed mapping of this slide, which covers an area of about $40 \mathrm{~km}^{2}$ and can be as thick as $250 \mathrm{~m}$, with an average thickness of about $100 \mathrm{~m}$. From the extent of the slide scar a displacement of ca. $200 \mathrm{~m}$ has been estimated along the basal decollement (Fig. 4). The geometry at the toe of the slide is difficult to resolve, but it seems that ductile deformation is partly absorbing the downslope displacement. The estimated volume is about $4.8 \mathrm{~km}^{3}$. Direct dating of the slide is difficult in principle and it had not been attempted during the marine survey. Nevertheless, the lack of visible sediments overlying the slide scar suggests that the slide may be a recent feature.

\section{Tsunamigenic potential assessment through numerical modelling}

Numerical modelling was applied to determine the capability of both the tectonic and the gravitational slope failure sources described in the previous section to generate tsunami waves along the coasts of eastern Sicily, and to discuss whether they can be proposed as responsible for the 11 January 1693 historical tsunami. 

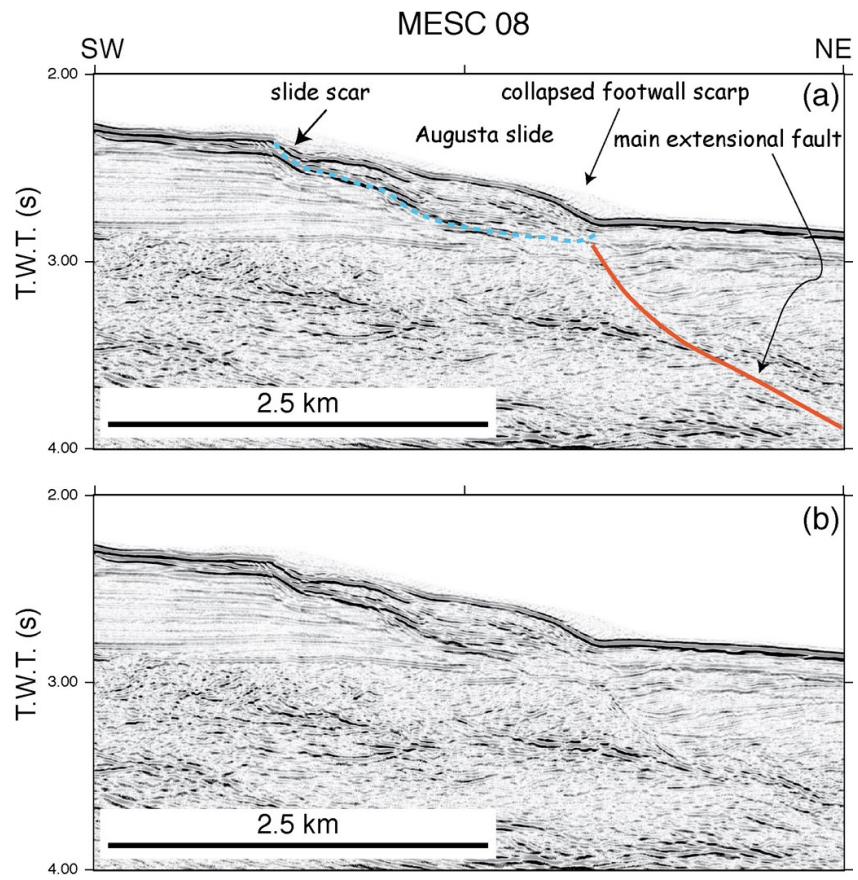

Fig. 4. Detail of seismic profile MESC 08 (Fig. 3). The interpreted seismic line (a) shows the collapsed sediments in the footwall scarp of the active splay of the major normal fault. The body of the slide has a volume of ca. $5 \mathrm{~km}^{3}$ and has slid about $200 \mathrm{~m}$. Vertical exaggeration ca. 1.7. (b) Non-interpreted seismic line.

From the numerical point of view, we treated separately the simulation of the generation and propagation of the tsunami waves.

\subsection{Tsunami generation by the earthquake}

In the case of the earthquake source, we used the approximation widely adopted in tsunami studies, consisting of taking the tsunami initial condition to coincide with the vertical component of the coseismic displacement of the sea-bottom caused by the earthquake. In turn, the coseismic deformation field is calculated by means of the Okada (1992) formulas, using an idealized figuration of a rectangular fault buried in a homogenous, isotropic and elastic half-space. A key step consists of determining the fault parameters to be used in the computation. The MESC seismic survey (Argnani and Bonazzi, 2005) puts constraints on the length, strike and dip of the fault. To represent approximately the irregular shape of the fault along strike, we adopted four different subfaults with different strike angles (varying in the range $330^{\circ}-$ $\left.360^{\circ}\right)$ and different lengths $(5.8 \mathrm{~km}$ to $10.2 \mathrm{~km}$, for a total of $28.5 \mathrm{~km}$ ), but sharing the same average dip angle $\left(28^{\circ}\right)$ and along-dip width $(16.5 \mathrm{~km})$. The rake angle of $270^{\circ}$ was imposed on the basis of the tectonics of the Malta Escarpment, which is dominated by extension. Moreover, since the observed fault cuts the seafloor, the depth of the simulated

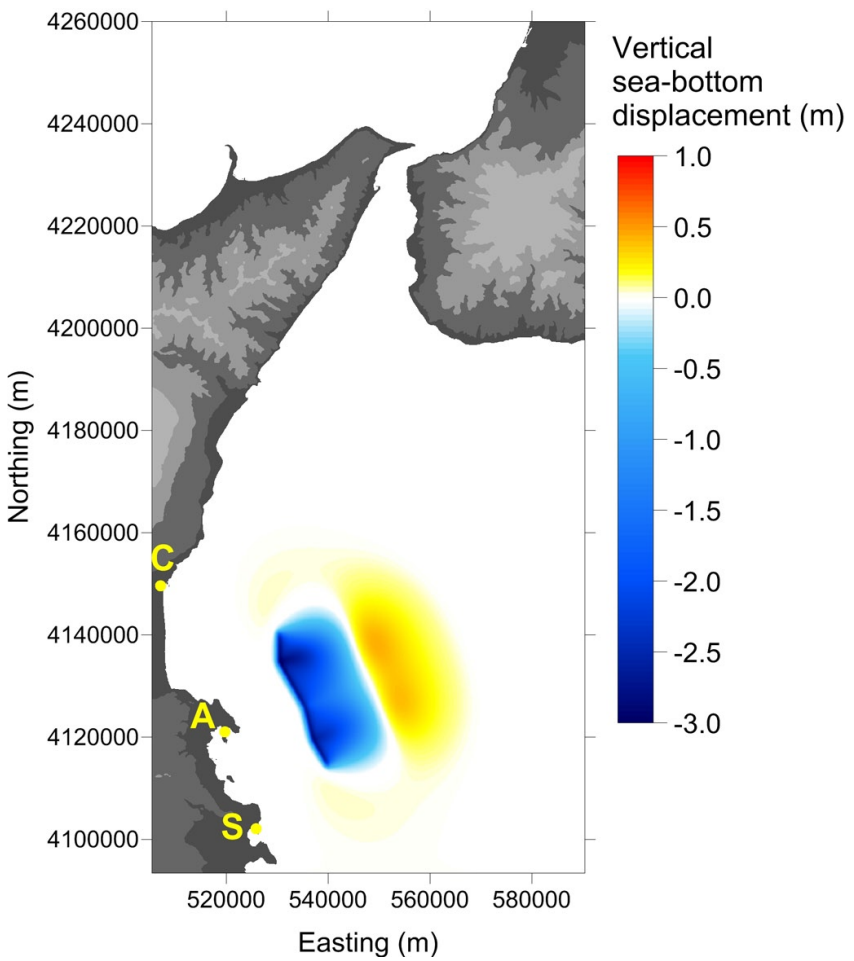

Fig. 5. Vertical coseismic sea-bottom displacement, coinciding with the initial sea surface displacement, computed for the main active extensional fault. "C", "A" and "S" indicate the position of Catania, Augusta and Siracusa, respectively.

fault's upper border was set to $0.5 \mathrm{~km}$. The slip on the fault was estimated from the seismic moment $M_{0}$ and the total fault area $A$ through the law

$M_{0}=\mu A \bar{u}$

where $\bar{u}$ is the average slip and $\mu$ is the rigidity of the Earth's crust in the source zone. Given a reference rigidity value of $30 \mathrm{GPa}$, since the area of the fault is of limited extension, we need quite a high slip to obtain a seismic moment which approximates the one postulated for the 1693 earthquake: with $\bar{u}=5 \mathrm{~m}$ we obtain $M_{0}=7 \times 10^{19} \mathrm{Nm}$, corresponding approximately to a magnitude $M=7.2$.

The resulting vertical seafloor deformation is shown in Fig. 5. Due to the low-angle geometry of the fault, the deformation field is characterised by a pronounced subsidence facing the coastline and by a smaller uplift zone offshore. This pattern is adopted as the initial tsunami condition.

\subsection{Tsunami generation by the landslide}

The landslide simulation was carried out through the numerical code UBO-BLOCK2, developed by the Tsunami Research Team of the University of Bologna. The model is Lagrangian: the sliding mass is split into a 2-D matrix of interacting, deforming, constant-volume blocks. The code 


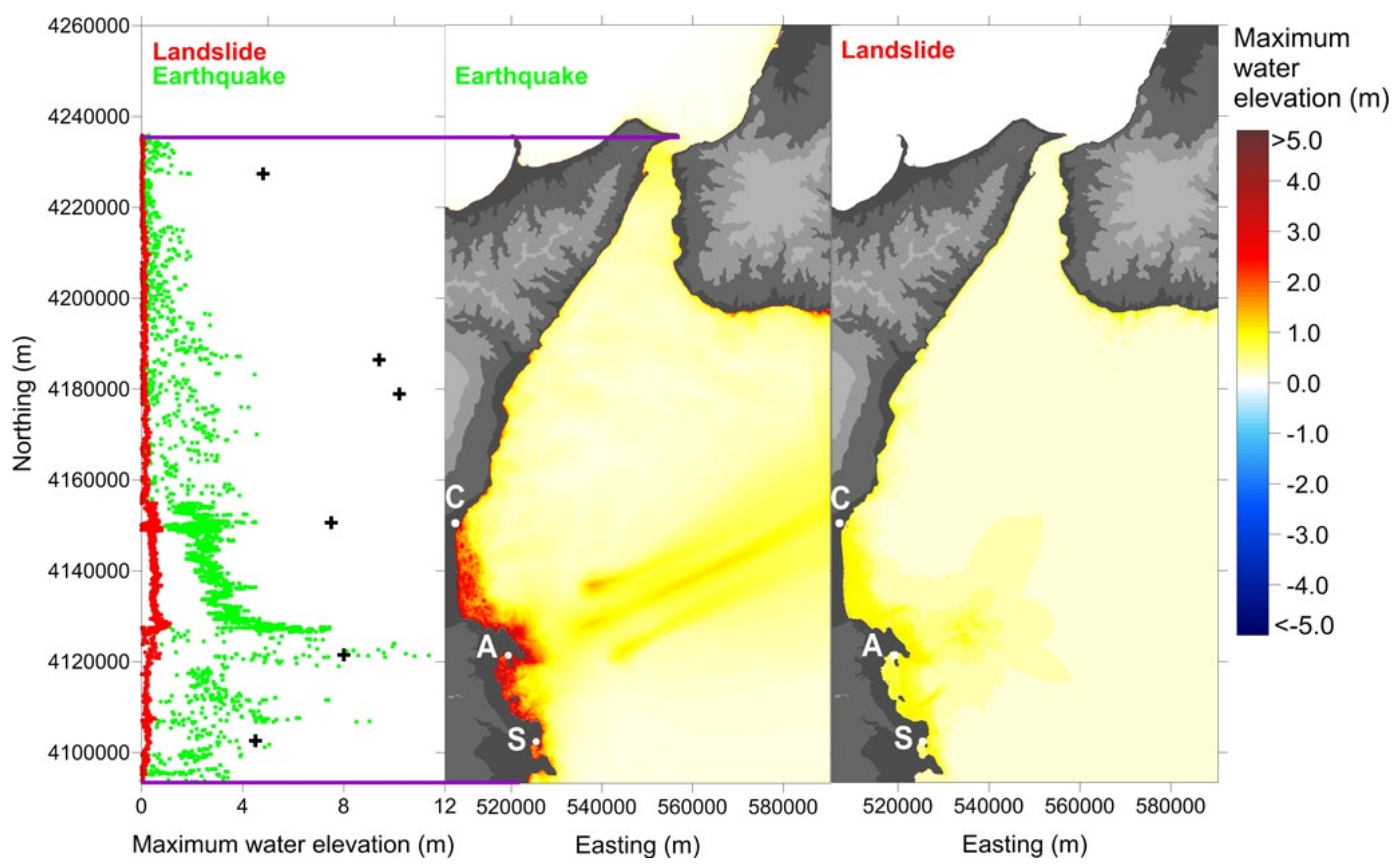

Fig. 6. Maximum water elevations computed for the tsunami generated by the active fault (central panel) and by the landslide (right panel). The left panel shows the comparison of the along-shore maximum water elevation distributions. "C", "A" and "S" indicate the position of Catania, Augusta and Siracusa, respectively. The black crosses are the run-up values computed by Gerardi et al. (2008) on the basis of the Hills and Mader (1997) relations.

has been extensively applied to several cases of tsunamigenic landslides (e.g. Tinti et al., 2006). The simulation performed in this study takes advantage of the results already presented by Armigliato et al. (2007) and by Tonini et al. (2011). We will only recall here that the main parameters used in the landslide simulation involve a total volume of $4.8 \mathrm{~km}^{3}$, a sliding mass of $12.8 \times 10^{9} \mathrm{~kg}$, a density of $2000 \mathrm{~kg} \mathrm{~m}^{-3}$, a maximum thickness of $250 \mathrm{~m}$, and a minimum depth of the scar of $1850 \mathrm{~m}$. The simulation performed with UBO-BLOCK2 reproduces the observation of a very limited landslide run-out distance (approximately $200 \mathrm{~m}$ ).

\subsection{Tsunami propagation}

The finite-differences numerical code UBO-TSUFD was used to simulate the tsunami wave propagation and impact on the coasts. The code, developed and maintained by the Tsunami Research Team of the University of Bologna, implements and solves the Navier-Stokes hydrodynamic equations in the approximation of shallow water, allowing to compute run-up and inundation. In the case of earthquakegenerated tsunamis, the coseismic deformation field is given as input to the code as a static initial condition. In the case of the landslide, the time derivative of the instantaneous sea surface elevation caused by the transit of the landslide on the sea-bottom represents the forcing term. In turn, this derivative is obtained from the time variation of the local thickness of the slide on the seafloor by means of a proper transfer function filtering out the high frequency signals. Further details are given in Tinti et al. (2006). UBO-TSUFD makes use of regularly-spaced grids that, depending on the application, can be nested to obtain fine space resolutions in selected target areas. The set of grids adopted in this study coincides with grids 3 (resolution of $200 \mathrm{~m}$ ) and 4 (resolution of $40 \mathrm{~m}$ ) used in the paper by Tonini et al. (2011). The topo-bathymetric data and the procedures used to obtain the computational grids are detailed in that paper.

\subsection{Results}

The historical information on the coastal effects produced by the 11 January 1693 tsunami mainly consists of the geographical distribution of the largest wave elevations along the eastern Sicily coastline and of the polarity of the first arrivals, which was negative in all the coastal places on the east coast of Sicily described in the coeval chronicles (see Piatanesi and Tinti, 1998; Tinti et al., 2004).

Figure 6 summarizes and compares the maximum water wave elevation patterns computed for both the earthquakeand the landslide-induced tsunamis over the entire computational domain. The leftmost panel represents the along-coast distribution of the maximum elevations for both generating mechanisms. A first comment regards the relative efficiency in generating tsunami waves of the two sources: the elevation values obtained for the earthquake are much larger than for the landslide. Secondly, the pattern of the field related to the 

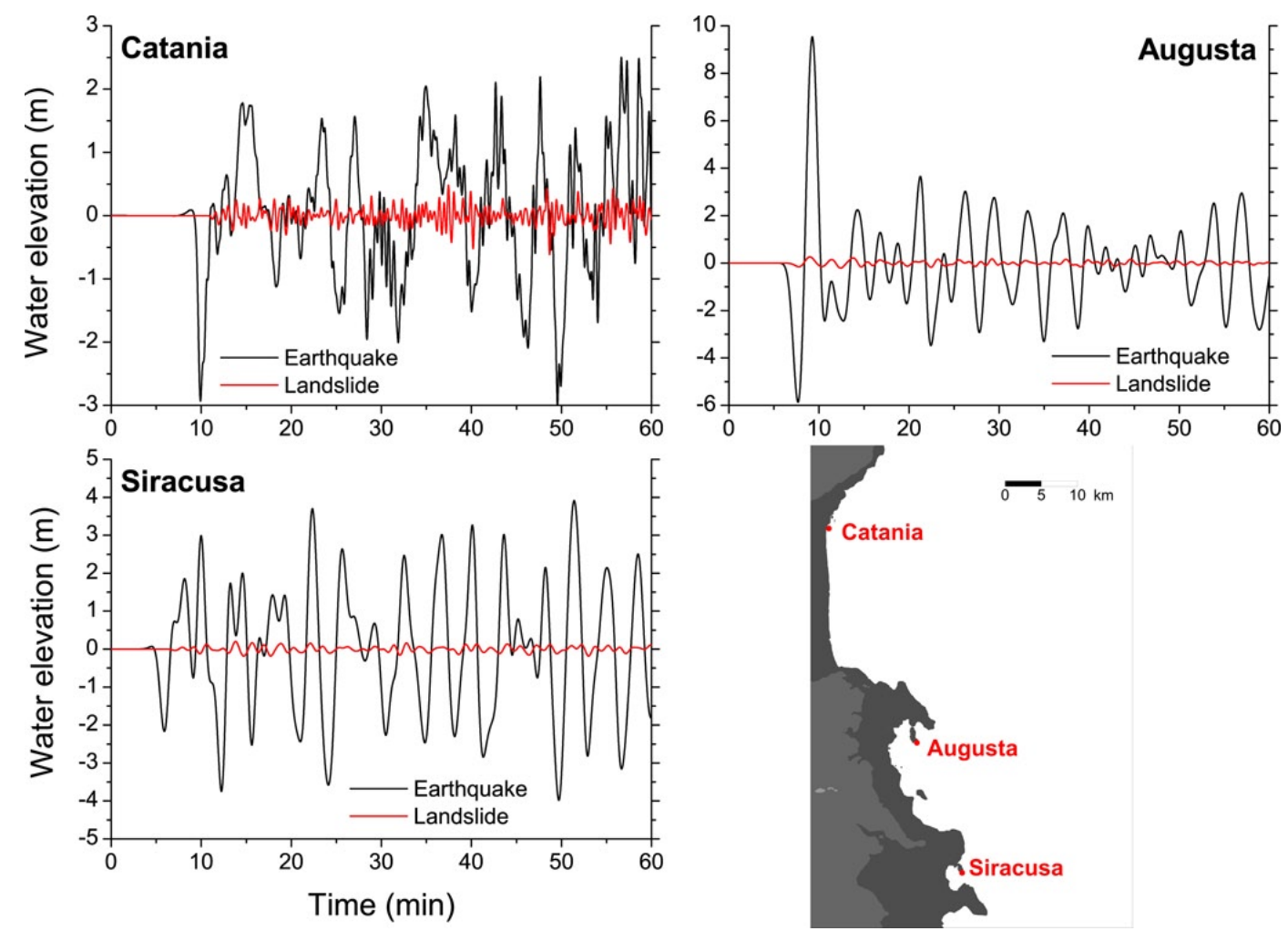

Fig. 7. Synthetic marigrams in the cities of Catania, Augusta and Siracusa computed for the active fault and for the landslide tsunamis. The localities are indicated in the bottom, right panel.

active fault is determined mainly by the position and directivity of the fault itself, and by the local bathymetry and coastal morphology. As a result, the zone between Catania and north of Siracusa is the one experiencing the largest tsunami impact. In more detail, the leftmost panel of Fig. 6 indicates tsunami elevations larger than $4 \mathrm{~m}$ in Catania and the north of Siracusa, while the coast in the vicinity of Augusta is impacted by waves with elevations larger than $10 \mathrm{~m}$. In contrast, the landslide is not able to produce waves larger than $1 \mathrm{~m}$ at any coastal location. Due to the landslide location the tsunami effects are the largest between Catania and just north of Augusta.

Figure 7 shows the wave elevation time series computed at three different grid points in the areas of Catania, Augusta and Siracusa, respectively. The main result concerns the polarity of the first arrival: in all three virtual stations the first significant signal is undoubtedly negative, in agreement with the historical accounts. Figure 7 provides information on the first tsunami arrival times, which are in the range of 4$8 \mathrm{~min}$. Although this information is not provided on the coeval document, it is worth mentioning it from an early warning system perspective. Finally, the earthquake and the landslide produce signals with different frequency contents. The tsunami generated by the earthquake shows a typical period around $8 \mathrm{~min}$, while the landslide induces shorter periods, in the order of few minutes. As a final observation, the fact that the virtual signal computed at Catania is more irregular than the ones obtained at Augusta and Siracusa should be attributed to the fact that Catania lies in the grid with the highest spatial resolution ( $40 \mathrm{~m}$ ), while Augusta and Siracusa are found in the 200-m resolution grid.

\section{Discussion}

The offshore fault that we have modelled, and that is part of the Malta Escarpment, is able to reproduce the tsunami waves, as described in the historical chronicles. On the other hand, the Augusta landslide that has been mapped at the base of the footwall scarp is not able to explain alone the observed tsunami, and in all grid points the computed maximum water elevations are always much smaller than those produced by the earthquake source.

The problem judging the "degree of agreement" of the numerical simulations with the historical accounts for an event that occurred in 1693 is not trivial at all. The most important "physical" information we can retrieve from the sources, regards the polarity of the first arrivals, negative along the entire Sicily eastern coast. Assessing run-up values in any location is rather critical. Only two such "quantitative measurements" for the 1693 tsunami are available in Augusta, as 
reported in Gerardi et al. (2008). In that study, the authors computed run-up values in a number of other localities by adopting the Hills and Mader (1997) relations. It should be noted that the relationships by Hills and Mader (1997) work well on highly idealised geometries and their application to realistic situations may introduce large uncertainties. One may be tempted to evaluate the matching between the computed values and our numerical results, as we do in the leftmost panel of Fig. 6; but we have to take these comparison with caution, because in Fig. 6 we are comparing two different tsunami metrics, the maximum water elevation (resulting from our modelling) and the run-up estimated by Gerardi et al. (2008). The numerical simulation of the run-up requires detailed information on the actual coastal topography in early 1693, which is not available to the authors. That is why our numerical model does not provide run-up values but elevations of waves that are normally expected to be smaller than run-ups. Nevertheless, it can be appreciated that our simulation reproduces well the one and only actual observation in Augusta. The matching is satisfactory in Siracusa, while in Catania the run-up modelled by our simulation underestimates that from Gerardi et al. (2008), and the same happens, even in a more pronounced way, towards the north.

Other faults have been proposed as responsible for the 11 January 1693 earthquake, either located onshore (e.g. D'Addezio and Valensise 1991; Sirovich and Pettenati, 1999, 2001; DISS Working Group, 2010; Di Bucci et al., 2010), or located offshore and related to the Calabrian Arc subduction fault plane (Gutscher et al., 2006).

As already mentioned, the choice of onshore faults as the source for the 11 January 1693 earthquake is mainly based on the distribution of seismic intensities inland (Fig. 1), since the main argument used in support is that a coastal inland fault can explain satisfactorily the severe damage observed on the coast as well as the way damage decays inland. It should be noted however that the estimates of the macroseismic intensity for an event that dates so far back in time as the January 1693 earthquake might suffer from severe uncertainties, especially because this event was preceded two days before by a strong disastrous foreshock, which contributed significantly to the total damage pattern. On the other hand, an onshore fault alone can hardly explain the tsunami generation and the main features of the observed impact (Tinti et al., 2001a).

One could try to solve the problem by invoking the occurrence of a suitable submarine landslide triggered by the earthquake; following this approach, Billi et al. (2010) inferred the occurrence of a landslide to the north of Mount Etna that was triggered by a fault located in the Hyblean Plateau. Such a position, however, is probably too far from the inferred seismogenic fault for the sediments to be destabilised by the seismic load induced by the earthquake; moreover, a landslide in that position would not produce the expected tsunami response with maxima between Catania and Siracusa. Finally, and most important, no recent submarine landslides of suitable size have been found in the area north of Mount Etna (see the comments of Argnani et al., 2009b on a tsunamigenic slide supposedly located in the same position). It is also worth stressing that Gerardi et al. (2008), analysing the inundation pattern of the 1693 tsunami along the Sicily coast and using a discriminatory tool introduced by Okal and Synolakis (2004) for near-shore tsunami sources, came to the conclusion that the characteristics of this tsunami were more compatible with an earthquake rather than with a landslide source. Our results support this conclusion, as we have demonstrated in this work that even a submarine landslide close to the coastal area, where the observed tsunami waves were larger, cannot reproduce the 11 January 1693 tsunami effects.

As for offshore sources in relation with the Calabrian Arc, we have to mention that the Calabrian subduction fault surface may be capable of generating tsunamigenic earthquakes of the required magnitude (Gutscher et al., 2006). However, given the large area of the surface rupture and the expected predominant strike of the rupture, the tsunami waves modelled from such a source are impacting strongly against the Calabrian coastline, with heights actually larger than that of the waves along the coast of Sicily. This result is disproved by historical chronicles, which do not report any major tsunami event along the Calabrian coast in January 1693.

The Augusta landslide is located at the base of the fault scarp and straddles the fault plane. In onshore palaeoseismology landslides in the vicinity of an active fault are commonly considered seismically triggered (e.g. McCalpin, 2009). The close spatial relationship between fault and landslide, also in the Augusta case, suggests that this could be the case also in our study area, and the Augusta landslide can be considered as a process contributing to the degradation of an active fault scarp (e.g. Wallace, 1977).

Although we cannot date the slide event, as the marine survey was not specifically planned for studying the landslide, no evidence arguing against a recent age has been found though. It is also worth considering that in marine area dating a landslide and correlating it to a seismogenic fault is a rather difficult task, even for recent events. For instance, both a seismogenic fault and a triggered landslide contributed to the July 1998 Papua-New Guinea tsunami (Matsumoto et al., 2003), making it one of the best documented examples of combined tsunami source. However, just from the data collected from the cruise purposely carried out after the July 1998 event (Matsumoto et al., 2003), it would be very difficult to date the landslide, if the earthquake and tsunami data were not pointing out the active source area.

In spite of the limited displacement and the rather deep water, the large volume of the Augusta slide is enough to generate a tsunami, but not as large as the 1693 event. In our preferred scenario, this landslide was seismically triggered by the 1693 earthquake and contributed to the fault-generated tsunami. 


\section{Conclusions}

The south-eastern region of Sicily has been affected by large historical earthquakes, one of which, occurring on the 11 January 1693 , has been considered as the largest earthquake in the history of Italy. This earthquake has also been accompanied by a large tsunami, suggesting a source located in the near offshore.

A realistic fault geometry, that has been derived from the interpretation of depth migrated seismic data, has been used for modelling the tsunamigenic source. Previous modelling, in fact, used only loosely constrained and idealized fault geometries (Tinti et al., 2001a; Tinti and Armigliato, 2003).

The outcomes of the numerical simulations indicate that the coastal segment suffering the strongest tsunami impact is the one running from Catania to Siracusa, where the first tsunami arrival was negative, in agreement with the historical accounts of the 11 January 1693 tsunami.

Recent offshore surveys have also identified a large size submarine slide (almost $5 \mathrm{~km}^{3}$ ) along the south-eastern Sicily slope. This slide, called Augusta slide, occurring just at the scarp of the active fault identified as the potential earthquake and tsunami source, and affecting the uplifted footwall sediments, has proven to have tsunamigenic potential. The tsunami of the 11 January 1693 can be explained by means of the offshore faulting alone, but a combination of earthquake faulting triggering the Augusta submarine slide is very likely.

Acknowledgements. The beginning of this work was partly funded by a GNDT project 2000-2002 "A Study to Evaluate the Hazard Related to Submarine Geological Processes: Earthquake, Tsunamis and Landslides". It is also acknowledged that part of this study was possible thanks to funds of the European project TRANSFER (Contract no. 037058). The comments of the guest editor D. Pantosti and of the two reviewers, S. Barbano and L. McNeill, greatly improved the paper. The language help given by L. McNeill has been particularly appreciated.

Edited by: D. Pantosti

Reviewed by: M. S. Barbano and L. McNeill

\section{References}

Adam, J., Reuther, C.-D., Grasso, M., and Torelli, L.: Active fault kinematics and crustal stresses along the Ionian margin of the southeastern Sicily, Tectonophysics, 326, 217-239, 2000.

Argnani, A.: Evolution of the southern Tyrrhenian slab tear and active tectonics along the western edge of the Tyrrhenian subducted slab, in: Collision and Collapse at the Africa-ArabiaEurasia Subduction Zone, edited by: Van Hinsbergen, D. J. J., Edwards, M. A., and Govers, R., Geol. Soc., Spec. Publ., 311, 193-212, 2009.

Argnani, A. and Bonazzi, C.: Malta Escarpment fault zone offshore eastern Sicily: Pliocene-Quaternary tectonic evolution based on new multichannel seismic data, Tectonics, 24, TC4009, doi:10.1029/2004TC001656, 2005.
Argnani, A., Brancolini, G., Bonazzi, C., Rovere, M., Accaino, F., Zgur, F., and Lodolo, E.: The results of the Taormina 2006 seismic survey: Possible implications for active tectonics in the Messina Straits, Tectonophysics, 476, 159-169, 2009a.

Argnani, A., Chiocci, F. L., Tinti, S., Bosman, A., Lodi, M. V., Pagnoni, G., and Zaniboni, F.: Comment on "On the cause of the 1908 Messina tsunami, southern Italy" by Andrea Billi et al., Geophys. Res. Lett., 36, L13307, doi:10.1029/2009GL037332, 2009b.

Armigliato, A., Tinti, S., Zaniboni, F., Pagnoni, G., and Argnani, A.: New contributions to the debate on the cause of the January 11th, 1693 tsunami in eastern Sicily (Italy): Earthquake or offshore landslide source (or maybe both)?, Eos, Transactions of the American Geophysical Union 88 (52), Fall Meeting Supplement, Abstract S53A-1019, 2007.

Barbano, S. and Rigano, R.: Earthquake sources and seismic hazard in southeastern Sicily, Ann. Geofis.-Rome, 44, 723-738, 2001.

Bianca, M., Monaco, C., Tortorici, L., and Cernobori, L.: Quaternary normal faulting in southeastern Sicily (Italy): a seismic source for the 1693 large earthquake, Geophys. J. Int., 139, 370394, 1999.

Billi, A., Minelli, L., Orecchio, B., and Presti, D.: Constraints to the Cause of Three Historical Tsunamis (1908, 1783, and 1693) in the Messina Straits Region, Sicily, Southern Italy, Seismol. Res. Lett., 81, 907-915, doi:10.1785/gssrl.81.6.907, 2010.

Boschi, E., Favali, P., Frugoni, F., Scalera, G., and Smriglio, G.: Mappa della massima intensità macrosismica risentita in Italia, Stabilimento L. Salomone, Roma, 1995a.

Boschi, E., Guidoboni, E., and Mariotti, D.: Seismic effect of the strongest historical earthquakes in the Syracuse area, Ann. Geofis.-Rome, 38, 223-252, 1995b.

Chiarabba, C., Jovane, L., and Di Stefano, R.: A new view of Italian seismicity using 20 years of instrumental recordings, Tectonophysics, 395, 251-268, 2005.

CPTI Working Group: Catalogo Parametrico dei Terremoti Italiani, versione 2004 (CPTI04), INGV, Bologna, 2004.

D'Addezio, G. and Valensise, G: Methodology for the characterization of the responsible seismogenetic structure of the earthquake of December 13, 1990, in: Contributi allo studio del terremoto della Sicilia orientale del 13 Dicembre 1990, Contributions to the earthquake studies of eastern Sicily, December 13, 1990, edited by: Boschi, E. and Basili, A., 115-125, 1991.

Di Bucci, D., Burrato, P., Vannoli, P., and Valensise, G.: Tectonic evidence for the ongoing Africa-Eurasia convegence in central Mediterranean foreland areas: A journey among long-lived shear zones, large earthquakes, and elusive fault motions, J. Geophys. Res., 115, B12404, doi:10.1029/2009JB006480, 2010.

DISS Working Group: Database of Individual Seismogenic Sources (DISS), Version 3.1.1: A compilation of potential sources for earthquakes larger than M 5.5 in Italy and surrounding areas, available at: http:/diss.rm.ingv.it/diss/, Istituto Nazionale di Geofisica e Vulcanologia, 2010.

Gerardi, F., Barbano, M. S., De Martini, P. M., and Pantosti, D.: Discrimination of tsunami sources (earthquake vs. landslide) on the basis of historical data in eastern Sicily and southern Calabria, B. Seismol. Soc. Am., 98, 2795-2805, 2008.

Gutscher, M. A., Roger, J., Baptista, M. A., Miranda, J. M., and Tinti, S.: Source of the 1693 Catania earthquake and tsunami (southern Italy): New evidence from tsunami modelling of a 
locked subduction fault plane, Geophys. Res. Lett., 33, L08309, doi:10.1029/2005GL025442, 2006.

Hills, J. G. and Mader, C. L.: Tsunami produced by the impact of small asteroids, Ann. NY Acad. Sci., 882, 381-394, 1997.

Lanzafame, G. and Bousquet, J. C.: The Maltese escarpment and its extension from Mt. Etna to the Aeolian Islands (Sicily): Importance and evolution of a lithosphere discontinuity, Acta Vulcanol., 9, 113-120, 1997.

Marani, M. P., Gamberi, F., Bortoluzzi, G., Carrara, G., Ligi, M., and Penitenti, D.: Seafloor bathymetry of the Ionian Sea, in: From seafloor to deep mantle: architecture of the Tyrrhenian backarc basin, edited by: Marani, M. P., Gamberi, F., and Bonatti, E., Memorie Descrittive della Carta Geologica D'Italia, Vol. 44, Plate 3, 2004.

Matsumoto, T., Tappin, D. R. and SOS Onboard Scientific Party: Possible Coseismic Large-scale Landslide off the Northern Coast of Papua New Guinea in July 1998: Geophysical and Geological Results from SOS Cruises, Pure Appl. Geophys., 160, 19231943, 2003.

McCalpin, J. P.: Paleoseismology, International Geophysics Series, Academic Press, 2nd Edn., 613 pp., 2009

Musumeci, C., Patane, D., Scarfi', L., and Gresta, S.: Stress directions and shear-wave anisotropy: observations from local earthquakes in southeastern Sicily, Italy, B. Seismol. Soc. Am., 95, 1359-1374, doi:10.1785/0120040108, 2005.

Okada, Y.: Internal deformation due to shear and tensile faults in a half-space, B. Seismol. Soc. Am., 82, 1018-1040, 1992.

Okal, E. A. and Synolakis, C. E.: Source discriminants for nearfield tsunamis, Geophys. J. Int., 158, 899-912, 2004.

Papaioannou, Ch. A., Papazachos, C. B., and Scordilis, E. M.: A catalogue of earthquakes in Greece and surrounding area for the period 550BC-1999, Publ. Geophys. Laboratory, University of Thessaloniki, 1, 333 pp., 2000.

Papazachos, B. C., Comninakis, P. E., Scordilis, E. M., Karakaisis, G. F., and Papazachos, C. B.: A catalogue of earthquakes in the Mediterranean and surrounding area for the period 1901-2007, Publ. Geophys. Laboratory, University of Thessaloniki, 2007.

Piatanesi, A. and Tinti, S.: A revision of the 1693 eastern Sicily earthquake and tsunami, J. Geophys. Res., 103, 2749-2758, 1998.
Pino, N. A., Piatanesi, A., Valensise, G., and Boschi, E.: The 28 December 1908 Messina Straits Earthquake (Mw 7.1): A Great Earthquake throughout a Century of Seismology, Seismol. Res. Lett., 80, 243-259, 2009.

Scandone, P., Patacca, E., Radoicic, R., Ryan, W. B., Cita, M. B., Rawson, M., Chezar, H., Miller, E., Mackenzie, J., and Rossi, S.: Mesozoic and Cenozoic rocks from Malta Escarpment (central Mediterranean), AAPG Bull., 65, 1299-1319, 1981.

Sirovich, L. and Pettenati, F.: Seismotectonic outline of SouthEastern Sicily: an evaluation of available options for the scenario earthquake fault rupture, J. Seismol., 3, 213-233, 1999.

Sirovich, L. and Pettenati, F.: Test of source-parameter inversion of the intensities of a 54,000-death shock of the seventeenth century in southeast Sicily, B. Seismol. Soc. Am., 91, 792-811, 2001.

Tinti, S. and Armigliato, A.: The use of scenarios to evaluate the tsunami impact in southern Italy, Mar. Geol., 199, 221-243, 2003.

Tinti, S., Armigliato, A., and Bortolucci, E.: Contribution of tsunami data analysis to constrain the seismic source: the case of the 1693 eastern Sicily earthquake, J. Seismol., 5, 41-61, 2001a.

Tinti, S., Maramai, A., and Graziani, L.: A new version of the European tsunami catalogue: updating and revision, Nat. Hazards Earth Syst. Sci., 1, 255-262, doi:10.5194/nhess-1-255-2001, $2001 b$.

Tinti, S., Maramai, A., and Graziani L.: The new catalogue of Italian tsunamis, Nat. Hazards, 33, 439-465, 2004.

Tinti, S., Pagnoni, G., and Zaniboni, F.: The landslides and tsunamis of the 30th of December 2002 in Stromboli analysed through numerical simulations, B. Volcanol., 68, 462-479, 2006.

Tonini, R., Armigliato, A., Pagnoni, G., Zaniboni, F., and Tinti, S.: Tsunami hazard for the city of Catania, eastern Sicily, Italy, assessed by means of Worst-case Credible Tsunami Scenario Analysis (WCTSA), Nat. Hazards Earth Syst. Sci., 11, 1217-1232, doi:10.5194/nhess-11-1217-2011, 2011.

Valensise, G. and Pantosti, D.: A 125 Kyr-long geological record of seismic source repeatability: the Messina Straits (southern Italy) and the 1908 earthquake (Ms 7 1/2), Terra Nova, 4, 472-483, 1992.

Wallace, R. E.: Profiles and ages of young fault scarps, north-central Nevada, Bull. Geol. Soc. Am., 88, 1267-1281, 1977. 